\title{
ANALYSIS OF SUPERVISOR COMPETENCIES IN IMPLEMENTING SCHOOL BASED MANAGEMENT TOWARDS QUALITY IMPROVEMENT OF SECONDARY SCHOOLS
}

\author{
Arfan Arsyad $^{\mathrm{a}}$ \\ a Universitas Negeri Gorontalo, Indonesia \\ Corresponding e-mail: arfanarsyad.ung@gmail.com
}

\begin{abstract}
This research is aimed, at: (1) developing competence test instrument that is valid in mapping competencies of school supervisors; (2) getting a description of competencies of school supervisors, which includes: (a) personality, (b) managerial supervision, (c) academic supervision, curriculum and teaching and learning management, (d) education evaluation, (e) school climate and culture development, (f) research and development, and (g) social. This research applies quantitative research by using explanatory descriptive method. The research population is 21 supervisors of the schools, which also makes the unit of analysis. Questionnaires and interviews are used for data collection. The collected data is analyzed by using descriptive analysis with percentage technique. The result of research, at: (1) developed test instrument to measure competencies of the supervisors and to map the competencies. (2) The results of the test indicate that the overall competencies of the supervisors are at fair category in the pre-test and become good at the post-test. The improvement on the post-test compared to the pre-test was the result of a treatment in the form of educating and training on the competencies of: personality; managerial supervision; academic supervision, curriculum and teaching and learning management; education evaluation; school climate and culture development; research and development; and social.
\end{abstract}

Keywords: competencies of school supervisors, school-based management implementatio 


\section{INTRODUCTION}

School principals and teachers have very strategic role in developing human resources as the main objectives of national education. Therefore revitalization and reorientation of their mindset are crucial. The position of school principals is very influential as it determines the success of schools in improving education quality [1]. The position of techers in classrooms is irreplaceable, which cannot be undertaken by technology tools and teaching and learning resources since they cannot interact and communicate with students effectively [2]. The research shows that the role of teachers in school innovation is about $37 \%$ and school principals $32,50 \%$. The research findings in Finland, Japan, Shanghai, and Hongkong show that $50 \%$ education quality at schools is determined by teachers.

The role of school supervisors as the work partners of school principals and teachers is very important in strengthening innovation and quality culture at schools. Therefore, school management reformation is mandatory to be in line with the local autonomy. The Regulation Number 20 Year 2003 on National Education System has established the implementation of school-based management. It gives unlimited authority to school principals and teachers to develop their schools. However, the fact at schools shows that the freedom for school principals and teachers to be innovative and creative still has boundaries, i.e. policies of the local governments/offices of education. The role of school supervisors as the representatives of offices of education is required so that school innovation and school-based management quality culture empowerment are implemented effectively. Ideally, a supervisor would position himself as "the teachers of teachers" and expected to act as the mediators between expectations of schools and requirements of policies set by local governments and/offices of education. Yet, the fact shows that school principals cannot do anything when encountering authority and arrogance of local governments towards school principals and teachers. This impacts on increased reluctance and pessimism of teachers in creating innovations and empowering quality culture, resulting in school-based management that is not in line with its purpose, i.e. school autonomy in decision-making.

Another factor that affects the low-level of supervisor's competency is the recruitment process where the selection is utilizing the instruments for teacher's competency test. Until this day the instruments for supervisor have not been developed yet. It is the reason that one of the focuses for this research is the development of the instruments for supervisor's test.

Furthermore, supervision refers to services to guide, facilitate, motivate, and assess teachers in teaching and learning implementation and professional development. This is relevant with the idea of Nawawi [3] and Soetopo [4]. Important aspects of supervision include: (1) provision of support and service to school principals, teachers, and staff, (2) personal quality development of teachers and staff, (3) professional development for school principals and teachers, and (4) motivation for school principals and teachers.

Nowadays some school supervisors still orient on monitoring with the main focus on administration when undertaking supervision activities [5]. Therefore partnership between teachers and school supervisors cannot be ideally created. Even teachers feel psychologically depressed, thinking that they will be assessed. Therefore supervision activities tend to be less meaningful for teachers. The activities will be effective if the depression can be changed and an environment where in services can be provided and needs fulfilled in an informal way. The less meaningful supervision activities, according to Imran [6], are caused by less appropriate supervision system and less healthy mentality of school supervisors. These factors influence the former: (1) supervision that still empasizes on administrative aspects and neglects professional aspects, (2) very little one-on-one meetings between school supervisors and teachers, (3) many school supervisors who do not teach any longer, so they need to have additional empowerment to keep up with the new development, (4) top-down management is generally implemented, and (5) the potential of teachers as supervisors are less optimized. These indicators reflect the latter: (1) rigid, less friendly relationship caused by authoritarian school supervisors makes teachers afraid to be open to the supervisors, (2) many school supervisors and teachers think they are already experienced and do not need to learn, and (3) it is easy for school supervisors and teachers to be satisfied with the learning results of students. The results of this research show that supervision activities in 2012 were not effective to improve professional capacity of school principals and teachers in teaching and learning. The results also indicate the need to improve the knowledge level of school supervisors on modern education supervision concepts.

Competencies of school supervisors, according to Harris [7], cover: (1) curriculum development, (2) 
provision of teaching materials, (3) preparation of teachers, (4) teaching and learning management, (5) teacher supervision on student services, (6) training material development, (7) school and community relation development, and (8) teaching and learning assessment. The Regulation of the Ministry of National Education Number 12 Year 2007 outlines these six competencies of school supervisors: (1) personality, (2) managerial supervision, (3) academic supervision, (4) social, (5) assessment, and (6) research and development.

School supervisors are resources of information that can provide answers to questions and facilitators for school principals and teachers in implementing school-based management. Therefore, they need to have and implement managerial supervision competencies reflected in their understanding of school-based management concepts to lead school principals and teachers in implementing schoolbased management at schools.

School-based management is an education strategy implemented at schools by empowering school community and other education users [8]. It requires the change of attitudes, behaviors, and commitment of all school elements, e.g. school principals, teachers, administration staff, students, parents, community, and government in school management and developmen [9]. These are in line with the concepts of Rosyada [10] dan [11]. Many education management experts have identified characteristics of school based management, which basically cover: (a) teacher salary system by work performance, (b) wide authority for school community members to manage schools, (c) effective empowerment of teachers, (d) participation of school community members, (e) authority decentralization, (f) independence given to schools for school program development, (g) partnership with different work forces, (h) school accountability, (i) continuous school promotion.

Based on the two main problems above, the objective of this research are: (1) to develop the competency test instrument that is valid in mapping competencies of school supervisors; (2) to describe the competencies of school supervisors, which includes: (a) personality, (b) managerial supervision, (c) academic supervision, curriculum and teaching and learning management, (d) education evaluation, (e) school climate and culture development, (f) research and development, and (g) social.

\section{2}

\section{RESEARCH METHODOLOGY}

Competencies of school supervisors analyzed in this research are classified into six: (1) personality, (2) managerial supervision, (3) academic supervision, curriculum management, and teaching and learning, (4) school climate and culture, (5) research and development, and (6) social. Quantitative approach of explanatory descriptive research is used to analyze the competencies of the school supervisors in this research. Data from the test is analyzed by percentage descriptive (\%). Data review is applied after the analysis to explain data in details through observations and interviews with school supervisors, school principals, and teachers. All 21 school supervisors are the population of this research who are also the respondents. The research data is collected through: (1) test, (2) observation, and (2) interview. The test is applied to map out the competencies of the school supervisors.

RESULTS AND DISCUSSIONS

\subsection{Establishment of Supervisory Competence Test}

The test is developed by using test development theory that includes: variable conceptual definition, variable operational definition, instrument indicators, items composition, content validation, instrument trial, empirical validation and reliability, difficulty level test, item discrimination index.

Competencies, sub-competencies, and indicators can be seen on Table I.

Table 1. Competencies, Sub-Competencies, and Indicators Instrument Mapping of Competencies of School Supervisor

\begin{tabular}{|c|c|c|c|}
\hline No & Competencies & Sub-Competencies & Indicators \\
\hline \multirow[t]{8}{*}{1.} & \multirow[t]{8}{*}{$\begin{array}{l}\text { Personality } \\
\text { (19 test items) }\end{array}$} & - Have integity & $\begin{array}{l}\text { One in word and action; high commitment to } \\
\text { accomplish given tasks }\end{array}$ \\
\hline & & Be responsible & Able to keep secret, sincere, fair, wise \\
\hline & & Be creative & Creative \\
\hline & & - Have problem-solving skills & Able to solve personal problems \\
\hline & & - Be curious & $\begin{array}{l}\text { - Visioner } \\
\text { - Able to work using IT } \\
\text { - Updated with science and technology } \\
\text { development }\end{array}$ \\
\hline & & - Be innovative & $\begin{array}{l}\text { - Able to encourage motivation in teachers to } \\
\text { work } \\
\text { - Able to develop ideas of teachers }\end{array}$ \\
\hline & & - Be honest & - Able to tell the truth \\
\hline & & - Bepatient & Calm, able to control emotions \\
\hline 2 & $\begin{array}{l}\text { Managerial } \\
\text { supervision } \\
\text { (30 test items) }\end{array}$ & $\begin{array}{l}\text { Demonstrate understanding of } \\
\text { basic concepts of teaching and } \\
\text { leaming supervision }\end{array}$ & $\begin{array}{l}\text { - Demonstrate understanding of the purpose of } \\
\text { supervision } \\
\text { - Demonstrate understanding of supervision } \\
\text { methods } \\
\text { - Demonstrate understanding of supervision } \\
\text { techniques } \\
\text { - Demonstrate understanding of supervision } \\
\text { principles }\end{array}$ \\
\hline
\end{tabular}






The validity test on 113 items shows that 7 test items are not valid. The level of the test reliability is 0,97 . The results of the test item analysis show that the difficulty level (DL) of 11 test items are at difficult level, 81 fair level, and 14 easy level. The discrimination index (DI) are $0.14-$ 92.00. Test items are considered acceptable from their discrimination index (DI), i.e. $0.40-1.00$ means the test items are acceptable; $0.30-0.39$ means the test items are acceptable but should be revised; $0.20-0.29$ means the test items should be revised; and $0.00-0.19$ means the test items are unacceptable/rejected. Based on empirical validation and reliability, difficulty level test, and item discrimination index, 100 test items are acquired as the instruments of the School Supervisor Competence Test.

\subsection{The Description of the School Supervisor Competence Test}

The description of school supervisors competency map through competency test which was conducted twice, the pre-test and the post-test. After the pre-test, a treatment was given in the form of educating and training to improve the competencies of the supervisors. On total average the pre-test result of the competencies of the supervisors are at fair level, while the post-test improved to good. The results are shown in Table II and Figure 1.

Table 2. Result Average from Pre-Test and PostTest

\begin{tabular}{|c|l|c|c|c|}
\hline No. & \multicolumn{1}{|c|}{ Competence Dimensions } & Code & $\begin{array}{c}\text { Pre-Test } \\
\text { Average }\end{array}$ & $\begin{array}{c}\text { Post-Test } \\
\text { Average }\end{array}$ \\
\hline 1. & Personality & K-1 & 52,13 & 87,55 \\
\hline 2. & Managerial supervision & K-2 & 40,32 & 70,35 \\
\hline 3. & $\begin{array}{l}\text { Academic supervision, curriculum and } \\
\text { teaching and learning management }\end{array}$ & K-3 & 36,10 & 75,79 \\
\hline 4. & Education evaluation & K-4 & 52,91 & 66,67 \\
\hline 5. & School climate and culture development & K-5 & 48,09 & 63,97 \\
\hline 6. & Research and development & K-6 & 45,24 & 71,05 \\
\hline 7. & Social & K-7 & 64,29 & 94,74 \\
\hline
\end{tabular}

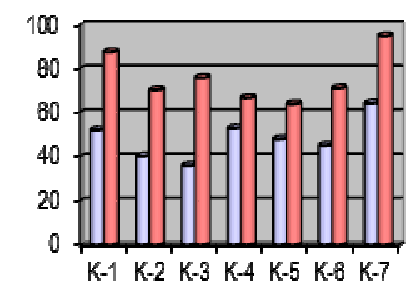

DThe Average of Pre-Test

- The Average of Post-Test

Fig. 1. Result Average from Pre-Test and Post-Test

Competencies of school supervisors are the alignment of capability, skills, and personality of the supervisors with their attitudes and behaviors when undertaking their job [12]. In other words, their competencies are the collection of knowledge, capability and beliefs shown in their actions for education/school quality improvement [13].

The preliminary competence test results show that, in average, the competencies of the secondary school supervisors in Boalemo District are still below the set expectations, which is at fair level. After the intervention of improving/ empowering the competencies through education and training, the 
post-test results show increased average categorized as good; the social competence is even at very good category.

The highest results are for social competence (K6 ), which are at fair category in the pre-test and very good category in the post-test. This means that social interaction of the school supervisors with their coworkers, related institutions that focus on school development, school principals, and teachers are quite good. Besides, tested aspects included in this competence are practical and related to daily activities, therefore it might be easy for them to respond. It is similar to the personality competence (K-1), which shows significant improvement in the post-test compared to the pre-test. Personality is a very personal factor, which is quite different from a school supervisor to another one. It shows when response is given. Therefore, after providing the supervisors with the education and training, the posttest was given resulting in the improved category from fair to good.

Managerial supervision competence (K-2) and academic supervision competence (K-3) are at the lowest category in the pre-test. After the education and training, the posttest was given and the results show a very significant improvement. Ideally these competencies should be at a higher category than other competencies as they relate to the core activities of school principals and teachers at schools. School supervisors' expertise in assessing school needs and developing school vision, mission and programs are parts of the managerial supervision competence. Their expertise in this competence is very important in implementing their main tasks, particularly in advising the implementation of school-based management. Masaong [14] states that if managerial supervision is to be effectively implemented, school supervisors are required to have a clear understanding of the concepts of school-based management. School-based management provides framework for school development process within open, transparent, accountable systems that enable schools to move forwards towards the expected direction.

Academic supervision is also referred to as teaching and learning supervision as its core is teaching and learning improvement. Therefore teachers are the targets of this supervision. Teaching and learning cannot be separated from curriculum, thus school supervisors are required to demonstrate understanding and mastery of curriculum applied by schools under their supervision or teachers in their classrooms [15].. The research findings show that the academic supervision competence of the supervisors in curriculum and teaching and learning (K-3) is at good and satisfactory category level. They have provided professional services to meet the needs of the school principals and teachers in teaching and learning improvement at schools.

Education evaluation competence (K-4) gets the score of 52,91 in the pre-test and 66,67 in the posttest. The test analysis indicates that even though there is improved competence, it is not that significant. This competence is crucial in teaching and learning; therefore it should be empowered to help the supervisors do the telated tasks effectively.

Education evaluation is the end of education process at all formal and non-formal education levels. It is aimed at providing reports to related parties on education process and product as the references for further decision-making in achieving the set education objectives.

School climate and culture competence $(\mathrm{K}-5)$ get the score of 48,09 in the pre-test and 63.97 in the post-test. Similar to the education evaluation competence, this competence is not significantly improved. It is already at the good category, yet more improvement is required.

The research on school climate and culture focuses on two aspects, i.e. school climate development with the indicators of effective conflict management; secure, conducive, orderly school environment, close/friendly communication, and appropriate school facilities; and school culture development with the indicators of school vision and mission based on school philosophy, focused on customers and courage to take risks, and oriented on teamwork (McCarthy \& Quinn, 2010)[16].

The test results of school climate and culture indicate that the role of school supervisors in empowering work culture/quality culture of teachers has not been effective. The interviews with the supervisors and the school principals indicate that the understanding level of the principals in work climate and culture development requires improvement. Work culture cannot be separated from school climate and culture; the better the school climate and culture, the better the work culture of teachers and staff. Besides, work culture depends on the levels of intellectual, emotional, and spiritual intelligences as well as work commitment of teachers and staff. This is in line with the concept of Glickman [17] that affirms great influence of level of commitment and level of intelligence on the work culture of teachers. The role of school supervisors as the teachers of teachers in motivating, supervising, and facilitating teachers in developing work culture is very strategic towards creating effective teaching and learning quality.

Research and development competence (K-6) is also an important competence that should be mastered by school supervisors [18]. The supervisors should provide assistance and advice for school principals and teachers in conducting research, 
particularly school or classroom action research to improve school management and classroom teaching and learning. The post-test results show that this competence has the average of 71,05 , which is at good category. This is an increased category from the pretest average of 45,24 , which is at fair category. However, the improved competence is not yet significant and requires intervention for improvement from the local governments/offices of education

\section{CONCLUSION}

This research has successfully developed a test instrument that can be used to test competencies of school supervisors. The instrument is created based on theories of test/instrument development. It is mandatory for school supervisors to master the competencies set for their position. The competencies are important to help them provide supervision for school managers to ensure that school programs are well implemented to achieve the set objectives. The research results show the competence map of secondary school supervisors in Boalemo District that is generally at good category. Of all the competencies, personality and social are at very good category; managerial supervision, academic supervision, curriculum and teaching and learning management, and research and development are at good category, requiring improvement to become very good category as they are crucial for school-based management and teaching and learning management.

\section{REFERENCES}

[1] Bouchamma, Y., \& Basque, M. (2012). Supervision Practices of School Principals: Reflection in Action. US-China Education Review, 7, 627-637. Retrieved from http://eric.ed.gov/?id=ED535512.

[2] Lee, J. Ding, D., \& Song, H. (2008). School Supervision and Evaluation in China: the Shanghai perspective. Quality Assurance in Education, 16(2), 148-163.

[3] Nawawi, Hadari. (1991). Administrasi Pendidikan. Jakarta: Gunung Agung

[4] Sutopo, Hendiyat. (2003). Kepemimpinan dan Supervisi Pendidikan Jakarta Bina Aksara.

[3] Kalule,L, \& Bouchamma, Y. (2014). Teacher Supervision Practices and Characteristics of In-school Supervisors in Uganda. Educational Assessment, Evaluation and Accountability, 26(1), 51-72. Kluwer Academic Publishers.

[4] Nawawi, Hadari. (1991). Administrasi Pendidikan. Jakarta: Gunung Agung
[5] Yildirim, M. C., \& Demirtaş, H. (2012). Evaluating the Teacher Supervision Practices at Primary Schools in Terms of Constructivist Learning Paradigm Principles. Hacettepe Egitim Dergisi,(43),495-507.

[6] Bates, A. J., \& Burbank, M. D. (2008). Effective Student Teacher Supervision in the era of No Child Left Behind. The Professional Educator

[7] Imron, Ali. (2012). Supervisi Pembelajaran Tingkat Satuan Pendidikan. Jakarta: Bumi Aksara.

[8] Nurkolis. 2003. Manajemen Berbasis Sekolah: Teori, Model dan Aplikasi. Jakarta: Gramedia.

[9] Katleen. C. (1998). School Based Management. NWREL. School Improvement Research Series http://www.ed.gov/databases/ERICDigest/index.

[10] Rosyada, Dede, (2004). Paradigma Pendidikan Demokratis Sebuah Model Pelibatan Masyarakat dalam Penyelenggaraan Pendidikan. Jakarta: Prenada Media,

[11] Duhou, Ibtisam. (2012). School Based anagement .Jakarta: Logos Wacana Ilmu

[12] Johnson, C., Haynes, C., \& Ames, J. O. (2007). Supervision Competencies for Fieldwork Educators. OT Practice, 12(22),

[13] Ehren, M. C. M., \& Visscher, A. J. (2008). The Relationships Between School Inspections, School Characteristics and School Improvement. British Journal of Educational Studies, 56(2),205-227

[14] Tyagi, R. S. (2010). School-based instructional Supervision and the Effective Professional Development of Teachers. Compare: A Journal of Comparative and International Education, 40(1), 111-125

[15] McCarthy, J., \& Quinn, L. F. (2010). Supervision in Teacher Education. International Encyclopedia of Education (pp. 615-621). Elsevier Ltd.

[16] Masaong, A.K. \& Ansar. (2011). Manajemen Berbasis Sekolah. Sentra Media.

[17] Glickman C.D. (1991). Developmental Supervision, Alexandria ASCD

[18] Nutchrat, P., \& Sumalee, C. (2012). The Validation of Integrating Teachers Competency and Participatory Supervision Model. Procedia - Social and Behavioral Sciences, 46, 4626-4631

Rawung, F. The Implementation of SchoolBased Management to Alleviate the Quality of Education in High Schools and Vocational Schools in Minahasa Regency. International Journal of Humanities and Social Science Invention, 4(7), 53-64. 2015.

[2] Jalaludin; Azwir, \& Akmal, N. Implementation of School-Based Management at SMA on District of North Aceh. Researchers World, 6(4), 35. 2015.

[3] Swift-Morgan, J. What Community Participation in Schooling Means: Insights from Southern Ethiopia. Harvard Educational 
Review, 76(3), 339-368. 2006. https://doi.org/10.17763/haer.76.3.e475j32j69q $27 \times 63$.

[4] Firman, H., \& Tola, B. The Future of Schooling in Indonesia. Journal of International Cooperation in Education, 11(1), 71-84. 2008.

[5] Bandur, A. School-based management developments and partnership: Evidence from Indonesia. International Journal of Educational Development, 32(2), 316-328. 2012. https://doi.org/10.1016/j.ijedudev.2011.05.007.

[6] Cranston, N. C. Collaborative decision-making and school-based management: Challenges, rhetoric and reality. Journal of Educational Enquiry, 2(2), 1-24. 2001.

[7] Abadzi, H. School-based management committees in low-income countries: Can they improve service delivery? Prospects, 43(2), 115-132.

2013. https://doi.org/10.1007/s11125-013-9267-9.

[8] Sumintono, B. School-Based Management Policy and Its Practices at District Level in the Post New order Indonesia. Journal of Indonesian Social Sciences Humanities, 2(May 1998), 41-67. 2009.

[9] Chen, D. School-based management, school decision-making and education outcomes in Indonesian primary schools. World Bank Policy Research Working Paper Series. 2011.

[10] Fernandez-Feijoo, B., Romero, S., \& Ruiz, S. Effect of Stakeholders' Pressure on Transparency of Sustainability Reports within the GRI Framework. Journal of Business Ethics, 122(1), 53-63. 2014. https://doi.org/10.1007/s10551-013-1748-5

[11] Ganimian, A. J. Why do some school-based management reforms survive while others are reversed? The cases of Honduras and Guatemala. International Journal of Educational Development, 47, 33-46. 2016. https://doi.org/10.1016/j.ijedudev.2015.12.001.

[12] Moradi, S., Hussin, S. Bin, \& Barzegar, N. School-Based Management (SBM), Opportunity or Threat (Education systems of Iran). Procedia - Social and Behavioral Sciences, 69 (Iceepsy), 2143-2150. 2012. https://doi.org/10.1016/j.sbspro.2012.12.179.

[13] Hadijaya, Y. School Based Management at Matauli 1 State Senior High School Pandan. Researchers World, 6(4), 55. 2015.

[14] Grauwe, a De. School-based management ( SBM ): does it improve quality? Quality, 1-14. 2005. 